Proceedings of the Seminar on the Social and Economic Effects of Earthquake Prediction, 12 October, 1977.

\title{
THE EFFECT OF EARTHQUAKE PREDICTION ON EARTHQUAKE INSURANCE IN NEW ZEALAND
}

\author{
M. Hellberg*
}

BACKGROUND TO EARTHQUAKE INSURANCE IN NEW ZEALAND

Earthquake insurance in New Zealand falls into two distinct categories each undertaken by a different type of organisation.

A. Earthquake and.War Damage Act 1944

Under the Earthquake and War Damage Act 1944 property which is insured under a contract of fire insurance made in New Zealand is automatically insured, with a few exceptions, against the following risks:

War Damage

Earthquake Shock

Earthquake Fire

Extraordinary storm, flood or volcanic eruption damage

Landslip Damage

Cover under this Act is limited to the Indemnity Value of the insured property up to the amount of fire insurance cover.

\section{B. Company Earthquake Insurance}

Private insurers issue covers for the difference between the indemnity value (of property insured under the Earthquake and War Damage Act) and the reinstatement or extra cost reinstatement value of suitable properties. Cover is also issued for demolition and removal of debris, loss of profits, loss of rents and other intangible losses. Private insurers can also cover items excluded under the Earthquake and War Damage Act, e.g. bridges, reservoirs, swimming pools, tunnels, etc.

Finally these Insurers also issue Public Liability policies which cover the legal liability of clients for loss or damage caused by them or their employees.

\section{INSURANCE AND THE EARTHQUAKE HAZARD}

The following comments are based on a recent report to UNESCO prepared by a reinsurer, setting out the difficulties of insuring the earthquake hazard.

In the true sense of the word "earthquake insurance" does not exist at all, in contrast to motor insurance or life insurance.

If it is true that the insurer is mainly a gambler, it cannot be denied that he is used to taking calculated risks and that the game has to follow certain rules:

- the insured event has to occur with a certain regularity, in a certain space of time;

* Earthquake and War Damage Commission.
- the sustained damage must be measurable, i.e. it must be possible to calculate the probability of occurrence and the degree:

- the risks must be spread geographically;

- the amount of the damage must be limited.

It is easy to see that the earthquake hazard does not play by these rules and, particularly in the property branches, deprives the insurer of the little security he has been given by experience collected over more than two centuries of activity.

In principle, earthquake insurance has thus no place in traditional insurance.

The main problem, however, is the fact that an insurance company does not have unlimited production capacity, i.e. capacity to absorb the risk. Even with the support of a very sophisticated international network to redistribute the risk, saturation is rapidly arrived at, as had been the case in Japan and Mexico, obliging companies to reduce the percentage covered. Even in New Zealand insurance companies had waiting lists of clients requiring cover following the 1942 Wellington earthquake.

All these aspects add up to the fact that companies in most countries have not promoted this product to build up an earthquake portfolio. They have accepted these risks mainly for commercial reasons "to offer a service to good clients". Their portfolios therefore comprise largely commercial or industrial risks. On the other hand, bearing in mind the fact that the persons most likely to take out this type of cover is the owner of industrial or commercial property feeling particularly exposed, it is not surprising that most risks are located in exposed areas, leading to a pronounced selection against the insurer.

It was due to the difficulties traditionally associated with earthquake insurance and in an effort to ensure the protection of most property owners that earthquake cover was introduced under the E.Q.W.D. Act 1944.

The basic cover offered by this Act has thus relieved some of the pressures on insurers in New Zealand that are being experienced elsewhere.

New Zealand is thus more highly insured against the earthquake hazard than probably any other country in the world.

\section{ENTER EARTHQUAKE PREDICTION}

I hope I have stressed the fact that insurance for the earthquake hazard is 
difficult enough without the addition of a further complication, i.e. earthquake prediction.

For the balance of this paper, let us assume that prediction of earthquakes has become an accepted science and that the general public are confident of their accuracy to a very great extent. They have lived with the situation for some time. Most earthquakes, however, still occur without warning.

\section{WHAT IS THE EFFECT OF EARTHQUAKE PREDICTION ON EARTHQUAKE INSURANCE}

Let us assume the prediction of an earthquake in a given area 18 months ahead.

A. Cover under the E.Q.W.D. Act

As has been experienced for some time there is a general increase in the number of new fire policies taken out with Insurers and in addition sums insured of existing policies are increased. The E.Q.W.D. Commission is not directly aware of these increases as the cover under the E.Q.W.D. Act automatically follows any adjustment of the fire contract. The question of nondisclosure of a material fact, i.e. that an earthquake has been predicted, probably does not apply as the information is general knowledge and the insurer and E.Q.W.D. Commission are presumed to be aware of the situation.

The E.Q.W.D. Commission is still considering whether it should take any action to "Freeze" the amount of insurance under the E.Q.W.D. Act from the date of any prediction. However, there are arguments for and against such action.

It is estimated that $85 \%$ of all property owners take out fire insurance, so at the most only $15 \%$ would take out cover where none existed previously. To freeze cover would penalise those who have legitimate reasons for requiring an increase in cover or the insurance of new property. Inflation is not the problem it used to be but there is still an increase in values during the period of the prediction.

In any event, it is only the major earthquakes that will result in total losses and the prediction of a moderate earthquake could result in beneficial increases in fire insurance and premium income without corresponding increases in earthquake claims.

\section{B. Company Earthquake Insurance}

It must be remembered that contracts of insurance are generally for periods of 12 months and there is no legal requirement on the insurer to offer renewal. Mortgagees have for many years entered into "Continuous Agreements" with Insurers which state that policies covering property in which they have a financial interest will not be cancelled without their authority.

Clients have requested and obtained amendments to their own policies which now give a right of renewal in the event of earthquake prediction. alterations to their reinsurance contracts to ensure continuance of this protection.

Both Insurers and clients can see advantages in entering into Long Term Agreements for the insurance of the earthquake hazard. There is closer co-operation between Insurers and their clients on mitigation of the earthquake hazard.

\section{APPLICATIONS FOR NEW POLICIES}

The public have grown used to the prediction of earthquakes and now analyse the likelihood and amount of damage to their properties before making a request for reinstatement or extra cost reinstatement insurance. These requests (for new insurance) are generally refused. However, where the predicted earthquake is not expected to cause serious damage or the request is from a valued client, cover could be arranged in one of the following ways.

A normal policy could be taken at normal rates but excluding any damage as a result of the predicted earthquake or a policy could be taken which does not exclude damage as a result of the predicted earthquake, at a premium commensurate with the risk.

A long term agreement would probably be required in order that the Insurer may recoup premium over a longer period in view of the risk taken.

Many policies have for some years included a "Capital Additions" clause which automatically insures new buildings and alterations to buildings up to an agreed amount subject only to quarterly declarations to the insurer.

\section{APPLICATIONS FOR INCREASES UNDER EXISTIÑG POLICIES}

The principal behind replacement type policies is that the property should always be fully insured, and valuations are obtained at each renewal to ensure that this is being done. In addition it is common to insure inflationary increases in the value of the property during the period of the policy and during rebuilding following damage. When the contracts were altered to entitle clients to renew policies during the existence of a prediction it was also agreed that any increase due to revaluation on renewal would be accepted.

\section{MITIGATION OF LOSS}

Most policies include a clause along the following lines "The Insured shall take all ordinary and reasonable precautions for the safety of the property insured".

It has not been satisfactorily resolved as to whether reasonable precautions include engaging the services of an engineer in the event of an earthquake prediction and carrying out any strengthening that he might recommend. Some Insurers engage engineers at their own expense to advise clients what action they should take to mitigate loss. There is still lively debate as to whether insurers should share in the cost of mitigation measures that they recommend.

Insurers have entered into close co-operation with their clients in relation 
to the insurance of high value, specialised property such as dams, bridges, etc. and mitigation measures are jointly agreed to as far as possible.

In addition there is close co-operation over Loss of Profits Insurance. There is some suggestion that these policies should be widened so that losses arising from abnormal conditions consequent upon prediction of an earthquake are payable in addition to losses consequent upon damage to insured property caused by the earthquake itself.

\section{PROPERTY VALUES}

A study on the effects of earthquake prediction in the United States concluded that property values would fall, and that some measures designed to stabilise property values after the earthquake prediction could include some Federally subsidised earthquake insurance.

Earthquake Insurance in America is not widely entered into by property owners.

With the high proportion of insurance of property in New Zealand the fall of property values will not be so great.

If a property is fully insured there is little reason to sell it solely due to fear of damage.

There will still be pressure on businesses to consider whether it is in their best interests to move their operations before an earthquake but even so it would probably not be economic to sell a building until after the earthquake as there will be a small depression in the property market due to other businesses in the same position.

Property values could actually rise in specific cases due to a combination of earthquake insurance and the prediction of a severe earthquake.

Imagine an advertisement along the following lines :-

"Business for Sale:

Government Valuation of Building (Brick)

$\$ 50,000$

Extra Cost of Reinstatement Earth- $\$ 500,000$

$\begin{array}{lr}\text { quake policy (transferable) } & \$ 50,000 \\ \text { Value of Machinery } & \$ 20,000 \\ \text { Replacement Earthquake policy } & \$ 100,000\end{array}$

Earthquake Loss of Profits Insurance also held.

M.8 Earthquake predicted within 5 months. What Offers?"

\section{ASSESSMENT OF DAMAGE AND RECONSTRUCTION}

It has always been difficult for Assessors to establish the amount of damage to property, particularly buildings, that has been caused by a specific earthquake. Prediction of earthquakes has now allowed insurers to arrange surveys of property in the area of the prediction by independent Assessors to photograph and record the pretarthquake condition of insured property. Jt has been necessary to include a suitable clause in insurance contracts to permit these surveys.
Assessors, Builders, Engineers, Local Bodies, Government Departments and other interested parties have been able to plan in considerable detail the priorities to be established in rebuilding damage expected to be caused by the earthquake and in arranging the necessary finance, materials, labour and expertise that will be required.

\section{FINANCIAL}

Preaiction of an earthquake will enable Insurers to establish with some accuracy the amount that will be required to settle claims and arrangements can be made to have the money available when required without possibly having to realise assets in an unfavourable atmosphere as could occur in the event of an unexpected earthquake.

\section{LIFE AND ACCIDENT INSURANCE}

I have been assured that prediction of earthquakes will not affect the Life Insurance Industry in New Zealand. Apparently the rates for life insurance are on a world wide basis and avoidance of losses by earthquake are unlikely to affect the rating structure.

Other than a possible publicity compaign in an endevour to reduce injuries or death arising from the predicted earthquake the Accident Compensation Commission is unlikely to be directly involved.

There have been suggestions from time to time, however, that as earthquake prediction is of direct benefit to these two organisations, they could contribute towards the salaries paid to workers on the one or two days they are required to stay away from work when the predicted earthquake is imminent.

\section{CONCLUSIONS}

Once again, I will stress that the earthquake hazard is probably the most unforgiving peril to underwrite and the prediction of specific earthquakes will only add to this difficulty.

On the other hand, I am quite sure that it will encourage greater co-operation and understanding between the insuring public and insurers and that Insurers will become a part of the management team in the mitigation of this hazard.

NOTE:

The Insurance Industry has not yet studied the problem of earthquake prediction. Assumptions made in this paper are illustrative only and do not represent any official attitude. 